\title{
Growth Performance and Nutrient Digestibility of Growing Pigs Fed Cassava Peel Meal Based Diets Treated with Exogenous Enzyme
}

\author{
Torhemen L.N.*, Ikurior S.A., Wuanor A.A. \\ Department of Animal Nutrition, University of Agriculture Makurdi, PMB, 2373, Makurdi Benue State, Nigeria. \\ Author for correspondence*:darlyn3x@yahoo.com
}

\begin{abstract}
A feeding trial was conducted to evaluate the growth performance and nutrient digestibility of growerfinisher pigs fed diets containing $0 \%, 50 \%, 75 \%$ and 100 $\%$ levels of cassava peel meal treated with 0.035 gNatuzyme $e^{\circledR} / 100 g$ CPM. Sixteen (16) pure bred male Landrace grower-finisher pigs, averaging $31.80 \mathrm{~kg}$ were allotted to four dietary treatments in a completely randomized design such that each pig was housed and fed individually as a replicate. Four experimental diets $T_{1}, T_{2}$, $T_{3}$ and $T_{4}$ were formulated and $0 \%, 50 \%, 75 \%$ and $100 \%$ maize was replaced with Natuzyme ${ }^{\circledR}$ treated cassava peel meal and fed until the pigs reached $60 \mathrm{~kg}+2 \mathrm{~kg}$ live weight. At the end of the feeding trial which lasted for 7, 7,8 and 9 weeks for treatment $T_{1}, T_{2}, T_{3}$ and $T_{4}$, respectively, two pigs from each dietary treatment were randomly selected and starved for 24hours; faecal samples were collected for seven days, oven dried, weighed and sampled for digestibility analysis. Feed intake and weight gain of pigs fed test diets decreased $(p>0.05)$ while, feed conversion ratio increased $(p>0.05)$ compared with the control. There was significant reduction $(p<0.05)$ in the cost of feed per kilogram live weight gain as supplemented CPM increased in diets of finisher pigs. Nutrient digestibility of dry matter, crude fiber, crude protein, ash and nitrogen free extract decreased significantly $(p<0.05)$ while ether extract digestibility decreased ( $p>0.05)$. 100\% maize replacement with CPM treated with $0.035 \mathrm{~g}$ of Natuzyme $e^{\circledR}$ in $100 \mathrm{~g}$ of feed for grower finisher pigs proved cheaper though with a slower growth rate.
\end{abstract}

Keywords- cassava peel meal, Natuzyme ${ }^{\circledR}$, growth performance, nutrient digestibility, pigs.

Abbreviations-CPM-cassava peel meal

\section{INTRODUCTION}

The pig has been noted to compete with human beings for available cereal and grains (Adesehinwa et al., 1998).In view of this development animal researchers have shifted their attention to materials that are available but underutilized as feed ingredients for livestock. One of such materials is the cassava peel, which is underutilized in Nigeria because it is often burnt or left to rot away on farms and homesteads after harvesting and processing of the tubers (Akinfala and Tewe, 2001). Cassava peel meal contains up to $5 \%$ crude protein, $20 \%$ crude fiber depending on the variety (Aro et al., 2010). The fibrous content of cassava peel meal has limited its use in monogastric nutrition. Hydrocyanic acid, an anti-nutritional factor is also present in cassava peel. However, sundrying appreciably reduces its level in the material (Aletor et al.,1997).Dietary addition of exogenous enzyme like Natuzyme ${ }^{\circledR}$ has been reported to enhance the breaking down of fibre encapsulating the more soluble constituents so that digestion can be effective. Effects on performance of grower-finisher pigs fed varying levels of cassava peel meal without exogenous enzyme have been investigated (Ikurior et.al., 1996).This study was conducted to investigate the effects of varying levels of cassava peel meal diets supplemented with Natuzyme ${ }^{\circledR}$ on growth performance and nutrient digestibility of grower-finisher pigs.

\section{MATERIALS AND METHODS}

The experiment was carried out at the Pig production unit on the Livestock Teaching and Research Farm, University of Agriculture, Makurdi, Benue State of Nigeria. Cassava peels were obtained from garri processing agro-allied smallscale industries in Makurdi metropolis. The peels were washed and sun dried for seven (7) days to reduce the moisture content to about $10 \%$. The peels were then crushed using a hammer mill to obtain cassava peel meal (CPM), sampled for analysis and stored in bags until included in the diets. 


\section{Experimental diets}

Four isonitrogenous experimental diets T1, T2, T3, and T4 were formulated as presented in Table 1 . T1 contained $0 \%$ cassava peel meal (CPM) without Natuzyme ${ }^{\circledR}$ and diets T2,
T3 and T4 contained CPM treated with $0.035 \mathrm{~g}$ Natuzyme ${ }^{\circledR} / 100 \mathrm{~g}$ at $50 \%, 75 \%$ and $100 \%$, respectively as replacement for dietary maize.

Table.1: $\quad$ Ingredient Composition of Grower-Finisher Pig Diets ( $\mathrm{g} / 100 \mathrm{~g}$ )

\begin{tabular}{|c|c|c|c|c|}
\hline \multirow[b]{4}{*}{ Ingredients } & \multicolumn{4}{|c|}{ Dietary Treatments } \\
\hline & & $\mathbf{T 2}$ & & $\mathbf{T 4}$ \\
\hline & \multicolumn{4}{|c|}{ Levels of Cassava Peel Meal Replacement } \\
\hline & $0 \%$ & $50 \%$ & $75 \%$ & $100 \%$ \\
\hline Maize & 52.00 & 26.00 & 13.00 & 0.00 \\
\hline Cassava peel meal & 0.00 & 26.00 & 39.00 & 52.00 \\
\hline Full fat soya bean & 25.00 & 26.00 & 28.00 & 30.00 \\
\hline Maize offal & 19.75 & 18.75 & 16.75 & 14.75 \\
\hline Bone meal & 2.50 & 2.50 & 2.50 & 2.50 \\
\hline Common salt & 0.50 & 0.50 & 0.50 & 0.50 \\
\hline Vitamins/Minerals & ${ }^{a} 0.25$ & 0.25 & 0.25 & 0.25 \\
\hline Natuzyme $^{\circledR}$ & - & + & + & + \\
\hline Zinc oxide ${ }^{b}$ & ++ & ++ & ++ & ++ \\
\hline Total & 100.00 & 100.00 & 100.00 & 100.00 \\
\hline \multicolumn{5}{|l|}{ Calculated analysis } \\
\hline \multicolumn{5}{|c|}{ Metabolizable energy } \\
\hline$(\mathrm{Kcal} / \mathrm{Kg})$ & $3,169.64$ & $2,817.54$ & $2,656.11$ & $2,495.70$ \\
\hline Crude protein $(\%)$ & 16.81 & 16.04 & 16.06 & 16.09 \\
\hline Dietary cost $(\mathbb{N} / \mathrm{kg})$ & 77.68 & 62.43 & 55.54 & 48.65 \\
\hline
\end{tabular}

a Biomix premix supplied the following per kg of diet: Vitamin A 12,000,000I.U, Vitamin D33,000,000 I.U ,

Vitamin B6 3,500 mg, Biotin $80 \mathrm{mg}$, Antioxidant 125,000 mg, Cobalt $250 \mathrm{mg}$, Selenium $250 \mathrm{mg}$,

Iron 40,000 mg, Manganese 70,000 mg, Copper 8,000 mg, Zinc 80,000 mg, Choline chloride 200,000 mg ,

Calpan 10,000 mg, Vitamin B2 5,000 mg, Vitamin B1 2,000 mg, Iodine 1, $200 \mathrm{mg}$, Niacin 40,000 mg.

Vitamin E 30,000 mg, Vitamin K3 2,500 mg, Folic acid 1,000 mg,

${ }^{\mathrm{b}}$ zinc oxide $0.0125 \mathrm{~g} / 100 \mathrm{~g}$, added to supply $100 \mathrm{ppm} \mathrm{Zn,} \mathrm{++} \mathrm{=} \mathrm{zinc} \mathrm{oxide}$

- = Natuzyme ${ }^{\circledR}$ not added, $+=0.035 / \mathrm{g}$ Natuzyme ${ }^{\circledR} / 100 \mathrm{~g}$ diet.

\section{Experimental design and management}

Sixteen (16) male grower pigs were randomly allotted to four dietary treatments each of which had four replicates. Each pig was served drinking water ad libitum. Daily routine management activities were cleaning of pens, provision of experimental diets and drinking water, observation of each animal to know their health status.Each experimental animal was housed in a $183 \times 75 \times 106 \mathrm{~cm}$ welded iron pipe, wire mesh, individual concrete floored pens while each pen housed four individual crates provided with concrete feeding and watering troughs measuring $52 \times 29 \times 21 \mathrm{~cm}$ and $47 \times 37 \times 26 \mathrm{~cm}$, respectively. The experiment was a completely randomized design.

\section{Data collection}

The mean weekly body weights and feed intake were recorded throughout the experimental period of 63days. Feed conversion ratio was calculated from feed intake and body weight gain. Feed cost $/ \mathrm{kg}$ gain and feed cost $/ \mathrm{kg}$ diet were calculated from prevailing local market price of feed materials.

Nutrient digestibility was determined by the use of two (2) pigs from each dietary treatment which were randomly selected and starved for 24 hours.A weighed amount of feed was offered daily and fecal samples collected for seven days, oven dried, milled and analyzed for dry matter, crude fibre, crude protein, ether extract, ash and nitrogen free extract using standard methods (AOAC, 1995) The 
proximate analysis of the experimental diets was also carried out using the same standard methods.

All data collected were subjected to analysis of variance using the procedure of Steel and Torrie (1980) and where significant differences were observed treatment means were separated using Duncan multiple range test (Duncan, 1955)

\section{RESULTS AND DISCUSSION}

The experimental diets contained between 16-17\% crude protein (Table 1) in order to meet the protein requirement of grower pigs recommended by NRC (1997). Similarly, the metabolizable energy of the diets $(2,495.70$ - 3,169-64 $\mathrm{kcal} / \mathrm{kg}$ ) though reducing as the level of supplemented CPM increased in diet, were also within the energy requirement of growing pigs.

Table.2: Effect of Diets containing CPM treated Natuzyme ${ }^{\circledR}$ on Performance of Grower-Finisher Pigs

\begin{tabular}{|c|c|c|c|c|c|c|}
\hline \multirow[b]{4}{*}{ Performance indices } & \multicolumn{4}{|c|}{ Dietary Treatments } & \multirow[b]{4}{*}{ SEM } & \multirow[b]{4}{*}{ LOS } \\
\hline & T1 & T 2 & T3 & T4 & & \\
\hline & \multicolumn{4}{|c|}{ Levels of cassava peel meal replacement } & & \\
\hline & $0 \%$ & $50 \%$ & $75 \%$ & $100 \%$ & & \\
\hline Number of pigs & 4 & 4 & 4 & 4 & & \\
\hline Average initial live weight $(\mathrm{kg})$ & 31.45 & 31.75 & 31.88 & 32.50 & 0.89 & NS \\
\hline Average final weight $(\mathrm{kg})$ & 61.38 & 60.50 & 61.25 & 60.75 & 0.94 & NS \\
\hline Average daily weight gain (kg) & 0.65 & 0.62 & 0.52 & 0.45 & 0.06 & NS \\
\hline Average daily feed intake (kg) & 1.63 & 1.77 & 1.53 & 1.35 & 0.16 & NS \\
\hline Feed conversion ratio & 2.55 & 2.85 & 2.93 & 3.03 & 0.15 & NS \\
\hline Feed cost/ kg live weight gain( & $198.84^{\mathrm{a}}$ & $177.93^{\mathrm{b}}$ & $162.73^{\mathrm{bc}}$ & $147.41^{\mathrm{c}}$ & 9.51 & $*$ \\
\hline Average number of days fed & 49.00 & 49.25 & 56.00 & 63.00 & 8.29 & NS \\
\hline
\end{tabular}

a,b,c Means within same row with different superscripts differed significantly $(\mathrm{p}<0.05)$

LOS $=$ Level of significance.; NS = Not significant $(\mathrm{p}>0.05) ; *=$ Significant $\mathrm{SEM}=$ Standard error of mean

The effect of the experimental diets on the growth response of grower- finisher pigs is presented in Table 2. It was observed that the diets had no significant effect $(p>0.05)$ on the live body weight, weight gain, feed intake and feed conversion ratio. Significant effect $(p<0.05)$ was observed for the feed cost/ $\mathrm{kg}$ live weight gain. These performance indices decreased as percent dietary maize replaced by CPM increased. This probably was due to CPM effect which increased the bulk of the feed thereby lowering the energy density of the diets and causing decrease in weight gain, feed intake and feed conversion ratio. This observed performance can be attributed to a synergy between the digestive system of the pig and the enhanced utilization of Natuzyme $^{\circledR}$ treated CPM diets by the grower finisher pigs. This is in agreement with findings of Ikurior et.al.(1996) who reported that as animals grow older they tend to handle fibre more efficiently and Chesson (2001) that enzymes are a rich source of high quality protein (amino acids) making up for the short fall in the low quality of crude protein in CPM. It has been reported by Beachemin et al. (2003) that high producing/ growing animals require high level of available energy to meet the demand for lactation or meat production over and above maintenance needs, thus enzymes fed to low energy/ high fibre diets would help bridge the gap between potential and actual performance of the animal by assisting to release more digestible energy from fibrous fractions for use by the animal. The significant difference $(\mathrm{p}<0.05)$ in feed cost $/ \mathrm{kg}$ live weight gain showed that it decreased at higher levels of CPM in the diets. Therefore, it was cheaper to feed pigs on Natuzyme ${ }^{\circledR}$ treated CPM diets than the control diet. This agrees with the finding of Adesehinwa et.al. (2008) who reported significant reduction in feed cost per kilogram live weight gain as a result of replacing maize in control diet with cassava peel supplemented with exogenous enzyme.

Table 3 presents the digestibility coefficient of growerfinisher pigs. Significant decrease $(p<0.05)$ in nutrient digestibility occurred as CPM replacement of maize increased in diets of finisher pigs. However, digestibility of all nutrients: $\mathrm{CP}, \mathrm{CF}$, EE, NFE and overall dry matter 
digestibility was high,ranging from 60-90 percent despite the fibrous nature of CPM. This is traceable to the interactive effect between the pig's digestive system and Natuzyme ${ }^{\circledR}$ multi- activity. This was capable of breaking down the fibre encapsulating the more soluble constituent for easy digestion by the pigs, thereby enhancing the digestibility of other nutrients as reported by Irekhore et al. (2006).

Table.3: Effect of Diets Containing CPM treated with Natuzyme ${ }^{\circledR}$ on Apparent Nutrient Digestibility Coefficients of GrowerFinisher Pigs.

\begin{tabular}{|c|c|c|c|c|c|c|}
\hline \multirow[b]{4}{*}{ Nutrients } & \multicolumn{4}{|c|}{ Dietary Treatments } & & \multirow[b]{4}{*}{ LOS } \\
\hline & T1 & $\mathrm{T} 2$ & T3 & $\mathrm{T4}$ & \multirow[b]{3}{*}{ SEM } & \\
\hline & \multicolumn{4}{|c|}{ Levels of Cassava peel meal replacement } & & \\
\hline & $0 \%$ & $50 \%$ & $75 \%$ & $100 \%$ & & \\
\hline Dry matter (\%) & $91.67^{\mathrm{a}}$ & $88.92^{\mathrm{ab}}$ & $84.76^{\mathrm{b}}$ & $77.69^{\mathrm{c}}$ & 2.06 & $*$ \\
\hline Crude fibre $(\%)$ & $87.13^{\mathrm{a}}$ & $80.92^{\mathrm{ab}}$ & $72.33^{b}$ & $63.32^{c}$ & 3.49 & $*$ \\
\hline Crude protein $(\%)$ & $94.75^{\mathrm{a}}$ & $92.77^{\mathrm{a}}$ & $90.49^{\mathrm{ab}}$ & $87.40^{\mathrm{b}}$ & 1.14 & $*$ \\
\hline $\operatorname{Ash}(\%)$ & $76.85^{\mathrm{a}}$ & $74.47^{\mathrm{ab}}$ & $70.71^{\mathrm{ab}}$ & $61.57^{\mathrm{b}}$ & 2.60 & $*$ \\
\hline Ether extract $(\%)$ & 87.40 & 89.17 & 84.02 & 86.77 & 1.22 & NS \\
\hline $\operatorname{NFE}(\%)$ & $93.48^{\mathrm{a}}$ & $89.87^{\mathrm{a}}$ & $88.16^{\mathrm{a}}$ & $80.73^{\mathrm{b}}$ & 1.87 & $*$ \\
\hline
\end{tabular}

a,b,c Means on the same row with different superscripts are statistically different $(\mathrm{p}<0.05)$, $\mathrm{NS}=$ not significant $(\mathrm{p}>0.05) ; *=$ significant $(\mathrm{p}<0.05) ; \mathrm{LOS}=$ level of significance

$\mathrm{SEM}=$ standard error of mean

\section{Conclusion and Recommendation}

In conclusion, the study revealed that the nutritive value of cassava peel meal as a feedstuff can be improved by treating it with Natuzyme ${ }^{\circledR}$ an exogenous enzyme at the rate of $0.035 \mathrm{~g}$ Natuzyme ${ }^{\circledR}$ per $100 \mathrm{~g}$ diet. The test diets compared favorably with the control diets in growth parameters. Cassava peel meal with $0.035 \mathrm{~g}$ Natuzyme ${ }^{\circledR} / 100 \mathrm{~g}$ of feed at $100 \%$ CPM replacement of maize for grower-finisher pigs gave the least cost of feed per kilogram live weight gain though with a slower growth rate and is hereby recommended for finisher pigs.

\section{REFERENCES}

[1] A.O.A.C (1995). Association of Official Analytical Chemists. $15^{\text {th }}$ edition. William Tryd Press. Richmond, Virginia. U.S.A.

[2] Adesehinwa A. O.K.,Dairo, F.A.S. and Olagbegi, B.S. (2008). Response of growing Pigs to Cassava Peel Based Diets Supplemented with Avizyme 1300: Growth, Serum and Haematological Indices. Bulgarian Journal of Agricultural Science. 14(5):491499.

[3] Akinfala, O. and Tewe, O.O. (2001). Utilization of whole cassava plant in diets of growing pigs in the tropics. Livestock Research for Rural Development 13 (5): 13-21.
[4] Aletor, V. A. and Fasuyi, A. O. (1997). Nutrient Composition and Processing Effect on Cassava Leaf (Manihotesculenta, Crantz) Anti nutrients. In: Proc. $2^{\text {nd }}$ Conference Livestock Production. 15-17 September 1996, Lagos, Nigeria, Pp 231 - 242.

[5] Aro, S.O., Aletor, V.A., Tewe, O.O. and Agbede. J.O. (2010). Nutritional Potentials of Cassava Tuber Wastes: A Case Study of a Cassava Processing Factory in South-Western Nigeria. Livestock Research for Rural Development 22(11).

[6] Beauchemin, K.A., Colonbalo, D., Morgari, D. P. and Yang, W.Z. (2003) Use of Exogenous fibrolytic enzyme to improve feed utilization by ruminants. Journal of Animal Science. 81 (E. Supp1.2) E. 37-E47.

[7] Chesson, A. (2001). Non- starch polysaccharide Degrading Enzymes in Poultry Diets: Influence of Ingredients on the Selection of Activities. World Poultry Science Journal. 5:251-263.

[8] Duncans, D.B. (1955). Multiple range and multiple Ftest. Biometrics, 11:1-42

[9] Ikurior S.A., Onuh, S.O and Tegbe, T.S.B. (1996). Assessment of practical potential of cassava peels meal for growing and growing-finishing pigs in subhumid tropics. Bulletin of Animal Health Production 44:209-124.

[10] Irekhore, O.T., Bamgbose, A.M. and Olubadewa, G.A. (2006). Utilization of Cassava Peel Meal as Energy 
source for growing pigs. Journal of Animal Veterinary Advances 5(10):849-851.

[11] National Research Council(1997). Nutrient Requirements of Swine. 10 ${ }^{\text {th }}$ Revised Edition. National Academy Press, Washington D.C. Pp 23-114.

[12] Steel, R.G.D and Torrie, J.A. (1980). Principles and Procedure of Statistics. A biometrical approach. $2^{\text {nd }}$ edition, McGraw Hill Book Co. New York, USA. 